\title{
Stress and Quality of Life of the Medical Student
}

\author{
Jorge André Cartaxo Peixoto ${ }^{1,2 *}$ and Gustavo Pereira Peixoto ${ }^{2}$ \\ ${ }^{1}$ Faculty of Medicine, Federal University of Cariri (UFCA), Brazil \\ ${ }^{2}$ Estácio/Faculdade de Medicina, Juazeiro do Norte, Brazil
}

Submission: September 25, 2020; Published: October 19, 2020

*Corresponding author: Jorge André Cartaxo Peixoto, Faculty of Medicine, Federal University of Cariri (UFCA), 284, Divine Savior Street, Downtown, Barbalha, Ceará 63180000, Brazil

\section{Abstract}

Background: The medical school requires a high performance, assertiveness, and productivity of its students and the price paid for the physical and mental health exhaustion has very severe consequences, both in the personal and professional spheres. This aspect reflects on the quality of life of its agents, usually causing illnesses such as stress, depression and even suicide.

Objective: To understand how the pressures exerted by work and by the community affect the mental health of these professionals, who often end up seeking different ways of escape from suffering, sometimes becoming chemical dependents of both licit and illicit drugs.

Results: According to our research the medical course causes disorders that are expressed in different ways. In this way, these syndromes and social pressures end up hurting the health of students and professionals who become patients. Because of the easy access to medicines they self-medicate to maintain an unsustainable appearance and often do not seek such important specialized help.

Limitations: Although it is a current theme, faced with the situational framework, it is difficult to find evidence for the group of students and professionals that fit into this situational clinical context.

Conclusion: Therefore, we realize how a lack of mental health management can adversely affect the practitioner's performance in the profession, with the patients, and how they can vehemently interfere with his / her interaction with family and friends.

Keywords: Stress; Quality of Life; Medical Student.

\section{Minireview}

A well-known public health problem that is prevalent among university students is the mental health [1]. Thus, charges in high performance, assertiveness, and productivity are shown to be crucial and indispensable qualities to qualify as a good doctor; however, this level of demand requires a cost and is not cheap. A study done among doctors and medical students in Australia has shown that these professionals are not the "supermen" that society wants them to be, so the price paid for the physical and mental health exhaustion has very severe consequences, both in the personal and professional spheres. Therefore, we realize how a lack of mental health management can adversely affect the practitioner's performance in the profession, with the patients, and how they can vehemently interfere with his / her interaction with family and friends [2] (Figure 1).

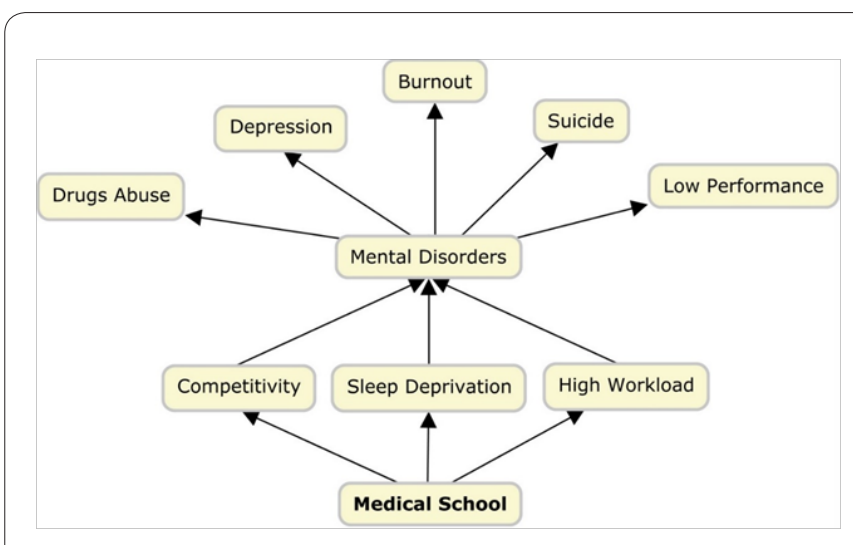

Made with cmapstools:Version: 6.03 License: Free for Commercial Use.

Figure 1:Sequence of the situational framework 
First, the boundaries between the definitions of mental illness must be established and defined as a symptomatic set [3]. However, the difficulty in this aspect is that because it is a huge taboo, the students and professionals of this area have their health gradually taken away during their shifts, consequently, the feeling of anxiety, panic syndrome, depression, and even suicidal thoughts among students are not uncommon [4]. Reflecting this logic, it is important to point out the example of doctors in the UK who usually feel helpless and when seeking help from supervisors are generally told to hide feelings and remain in a status quo, as they need to maintain an image of authority and power. Also, phrases of effects silenced professionals leading them to believe that admitting their problems would suggest an inability to deal with "being" a doctor and that this would do harm to their work and status [5]. Another strongly impacting aspect among these professionals is the ease they have of having access to any kind of medication making self-medication a routine practice and quite dangerous, regardless of the degree of knowledge of these doctors. Since when it comes to health itself, such professionals can act irrationally and paradoxically. Thus, the complexities concerning self-diagnosis, self-referral, and self-treatment among physicians are severe and may have repercussions both on their health and on quality of patient care. So, one should question: if doctors cannot be trusted to seek care like patients, for their own physical and mental health, how can they be trusted for their patients [6]?

Bringing this reality to the undergraduate medical students, it is perceived that these pressures exceed the natural boundaries and attack the strength of vitality of the students, that is, cognitivebehavioral functions are impaired and the stress have the capacity to affect the patient relationship and also can deteriorate the student's mental health. Thus, in several cases, some mental illnesses are considered common among students of this course, such as depression, panic syndrome, anxiety syndrome, binge eating disorder and nervous bulimia [7]. Such a perspective highlights cruel complications of various problems faced by social pressures and too many charges arising from the responsibility of the medical "being", in addiction sleep deprivation experiences evidence that no aspect of human biology outweighs unimpaired sleep deprivation. There is also an increased predisposition to the risk of cancer, heart attack and Alzheimer's disease [8]. Indeed, as has already been said, suicide thoughts are not uncommon among medical residents, which is often more common in women due to the large family commitments to household and childcare tasks [9].

Furthermore, the repercussions of these various psychological symptoms on the life of physicians highlight problems ranging from the performance in the profession to the relation to the patient and to the living with friends and family. A growing body of research shows that syndromes such as burnout and physician depression are linked to medical errors and depersonalized consultations, which are often less effective. Highlighting this logic, pediatric residents in three high-potency training programs showed that those who were depressed missed six times more medication errors than those who were not. This study and others also found that burnout residents were more likely to perceive that they were making mistakes, even if they were not committing them [10].

In this way, we perceive how the lack of administration of mental health can negatively affect the performance of the physician in the profession and with the patients. Another example of how depression can affect doctors' lives, Dr. Daksha Emson, a talented psychiatrist, killed herself and her three-month-old baby, Freya, in 2000. The incident occurred during a psychotic episode that was an Emson's bipolar affective disorder, which had been triggered by an outbreak of postpartum depression. From this point of view, one can see how the psychological problems arising from the stresses to which the doctors are subjected can interfere in his interaction with his family and friends $[11,12]$ (Table 1$)$.

Table 1: Percentage of burnout and number of suicides.

\begin{tabular}{|c|c|}
\hline \multicolumn{2}{|c|}{ Percentage of Burnout and Number of Suicides } \\
\hline Pediatrics Residents & 55 to $60 \%$ \\
\hline Medical faculty members & 20 to $49 \%$ \\
\hline Number of suicides & 300 to 400 physicians \\
\hline Experience burnout at some point & Up $50 \%$ \\
\hline
\end{tabular}

Percentage of burnout and number of suicides (The New York Times)

[9].

\section{References}

1. Kamimura A, Trinh HN, Johansen M, Hurley J, Pye M, et al. (2018) Perceptions of mental health and mental health services among college students in Vietnam and the United States. Asian Journal of Psychiatry 37: 15-19.

2. The Guardian (2017a) 'I cried every day at work': mental health among doctors is still taboo.

3. Spitzer R, Endicott J, Micoulaud Franchi J (2018) Medical and mental disorder: Proposed definition and criteria. Annales Médicopsychologiques, revue psychiatrique 176(7): 656-665.

4. Pedrelli P, Nyer M, Yeung A, Zulauf C, Wilens T (2015) College Students: Mental Health Problems and Treatment Considerations. Academic Psychiatry : The Journal of the American Association of Directors of Psychiatric Residency Training and the Association for Academic Psychiatry 39(5): 503-511.

5. The Guardian (2016) 'Burnout and depression': the doctors struggling with their mental health.

6. Montgomery AJ, Bradley C, Rochfort A, Panagopoulou E (2011) A review of self-medication in physicians and medical students. Occupational Medicine 61(7): 490-497.

7. Adhikari A, Dutta A, Sapkota S, Chapagain A, Aryal A, et al. (2017) Prevalence of poor mental health among medical students in Nepal: a cross-sectional study. BMC Medical Education 17: 232.

8. The Guardian (2017b) 'Sleep should be prescribed': what those late nights out could be costing you. 
9. The New York Times (2017a) Being a Doctor Is Hard. It's Harder for Women.

10. The New York Times (2017b) Taking Care of the Physician.

11. The Guardian (2018) For doctors with mental illness, 'help me' can be the hardest words.

This work is licensed under Creativ Commons Attribution 4.0 License DOI:10.19080/PBSIJ.2020.15.555918
12. Merlo LJ, Curran JS, Watson R (2017) Gender differences in substance use and psychiatric distress among medical students: A comprehensive statewide evaluation. Substance Abuse.

\section{Your next submission with Juniper Publishers} will reach you the below assets

- Quality Editorial service

- Swift Peer Review

- Reprints availability

- E-prints Service

- Manuscript Podcast for convenient understanding

- Global attainment for your research

- Manuscript accessibility in different formats ( Pdf, E-pub, Full Text, Audio)

- Unceasing customer service

Track the below URL for one-step submission https://juniperpublishers.com/online-submission.php 